\title{
Aerodynamic Interceptors Efficiency for Subsonic Missiles Roll Attitude Control
}

\author{
Slobodan Mandić ${ }^{1)}$ \\ Miloš Pavić ${ }^{1)}$ \\ Bojan Pavković ${ }^{1)}$ \\ Milan Ignjatović ${ }^{1)}$ \\ Goran Ocokoljić ${ }^{1)}$
}

\begin{abstract}
The excessive roll of air-launched missiles is a result of disturbances during the flight due to airframe misalignment, asymmetric control in pitch and yaw planes, atmospheric disturbances or large torque disturbances in the vicinity of aircraft. In order to overcome the undesired roll motion effects, most missiles are equipped with the roll autopilots to stabilize their roll attitude in spite of disturbances. In this paper, the classical and optimal control theory are applied in the design of a roll autopilot of the missiles controlled by the aerodynamic interceptors with the roll rate feedback in the inner loop and the roll angle in the outer loop. The desired command is transformed to the aerodynamic interceptor deflection by the pulse width modulation. The efficiency of the roll autopilot is verified on a wind tunnel model mounted on a free rotating adapter which enables movements around the longitudinal axis of the model support system. Based on the wind tunnel model response to the interceptor command, the transfer function of the wind tunnel model is determined. The results of the experiments show the influence of the roll autopilot gains on the wind tunnel model response. The wind tunnel experiments have also shown that missile oscillations occur due to the pulse width modulated deflection of the aerodynamic interceptors.
\end{abstract}

Key words: autopilot, avionic missile, missile control, missile roll, roll angle, aerodynamic inteceptor, optimal control, impulse modulation, aerodynamic testing, testing results.

\section{Nomenclature}

$\mathbf{A}_{r} \quad$-stability matrix

B $\quad$ - control matrix

$I_{x} \quad$-longitudinal moment of inertia of the missile

$J \quad$-quadratic performance index

$\mathbf{K} \quad$-gain matrix of the optimal control law

$K \quad-$ gain of the roll autopilot [volt $/ \mathrm{rad}]$

$K^{\prime} \quad$-gain of the roll autopilot [volt/volt]

$K_{a} \quad$-gain of the aerodynamic interceptors transfer function

$K_{a} \quad$-gain of the aerodynamic interceptors transfer function

$K_{p}^{\prime} \quad$ - roll rate feedback gain [ $\mathrm{volt} / \mathrm{rad} / \mathrm{s}$ ]

$K_{\phi} \quad$-gain of the roll transfer function

$K_{\phi}^{\prime} \quad-$ roll angle feedback gain [volt $\left./ \mathrm{rad}\right]$

$K_{\phi(W T)} \quad$-gain of the wind tunnel roll transfer function

$L \quad$-roll moment

$L_{\text {dist }} \quad$-disturbing roll moment

$L_{p} \quad$-roll damping derivative

$L_{\xi} \quad$-roll moment derivative due to interceptor deflection

p $\quad$-missile roll rate $\tilde{p} \quad$-measured roll rate

$p_{\max } \quad-$ maximum allowed roll rate

Q - weighting matrix of the optimal performance index

$\mathbf{R} \quad$-weighting matrix of the optimal performance index

S - solution of the Riccatti matrix equation

$T_{1} \quad$-time interval of the positive deflection of aerodynamic interceptors

$T_{2} \quad$-time interval of the negative deflection of aerodynamic interceptors

$T_{a} \quad$-time constant of the aerodynamic interceptors transfer function

$T_{p d} \quad$ - pure delay time constant

$T_{P W M} \quad$-time interval for pulse width modulation of the aerodynamic interceptors deflection

$T_{\phi} \quad$ - time constant of the roll transfer function

$T_{\phi(W T)}$-time constant of the wind tunnel roll transfer function

u $\quad$-control vector

$U_{\phi_{d}} \quad$-demanded roll angle in voltage

$W_{a}(s) \quad$-transfer function of the aerodynamic interceptors actuation system

$W_{p d}(s)$-pure delay transfer function

$W_{\xi}^{p}(s) \quad$-roll transfer function of the missile

\footnotetext{
1) Military Technical Institute (VTI), Ratka Resanovića 1, 11132 Belgrade, SERBIA

Correspondence to: Slobodan Mandić; e-mail: msmanda@mts.rs
} 


$$
\begin{aligned}
& W_{\xi(W T)}^{p}-\text { roll transfer function of the wind tunnel model } \\
& \mathbf{x}_{r} \quad-\text { state space vector of the missile roll channel } \\
& \phi \quad-\text { roll angle } \\
& \phi_{d} \quad \text {-demanded roll angle } \\
& \tilde{\phi} \quad \text {-roll angle obtained by roll rate integration } \\
& \phi_{\max } \quad-\text { maximum allowed roll angle } \\
& \xi \quad-\text { total roll command } \\
& \xi_{c} \quad \text {-roll command } \\
& \xi_{c d} \quad-\text { demanded roll command } \\
& \xi_{\text {dist }} \quad \text {-equivalent disturbing roll control } \\
& \xi_{\max } \quad-\text { maximum allowed roll control } \\
& \omega_{n_{\phi}} \quad-\text { desired natural frequency } \\
& \varsigma_{n_{\phi}} \quad \text {-desired damping factor }
\end{aligned}
$$

\section{Introduction}

$\mathrm{R}_{\mathrm{b}}^{\mathrm{o}}$ OLL of air-launched missiles during the flight is caused by airframe misalignment, asymmetric control in pitch and yaw planes, atmospheric disturbances, or large torque disturbances in the aircraft vicinity. These disturbances may result in excessive missile roll. The cross coupling of guidance commands results in inaccurate missile maneuvers due to excessive roll. The influence of the cross coupling can be minimized or nullified by roll rate or roll attitude stabilization and, as a result, the maneuvers of a missile with a roll autopilot are appropriately controlled by the guidance commands.

Minović analyzed a design of the roll attitude autopilot with the roll angle feedback measured with free gyro of the missile with the aerodynamic interceptors [1]. Free gyro characteristics were given in the form relay element with dead zone. The gain necessary for the stability of the autopilot closed loop was determined analytically after linearization of the nonlinear characteristics of the relay element with dead zone.

Garnel analyzed the design of the roll attitude autopilot with the roll angle in feedback by the classical linear control theory $[2,1]$. The phase lag and phase advance compensators were used to ensure the stability of the closed loop. The numerator time constant of the phase advance compensator was selected to cancel the time constant of the missile transfer function. The phase lag compensator was used to lower the crossover frequency and increase the stability of the roll autopilot. The stability of the closed loop was analyzed by the Bode diagram of the open loop.

Blakelock used a root locus plot for the design of the roll attitude autopilot [3]. The stability of the closed loop was obtained by introducing the lead circuit. Special attention was paid to the influence of the roll damping coefficients derivatives on the root locus poles movement in the root locus plane. The larger roll damping coefficients derivatives, the less requirement for the lead circuit.

An alternative to the roll attitude autopilot with the roll angle in feedback is a two-loop roll attitude autopilot with the roll rate feedback in the inner loop and the roll angle feedback in the outer loop [4]. The inner roll rate feedback is used to increase damping by means of stability augmentation and the inner loop gain is selected to move the root locus poles farther out along the negative real axis.

A special case of the application of the optimal control to the missile guidance and control system is regulating control where the desired state values are zero. This type of regulating control is defined by the minimization of the quadratic performance index (or cost function) $[4,5]$. The control input is a function of the state vector and it is less sensitive to noise and external disturbances. The control input gains are constant for the constant parameters of the state space matrix. Since the missile guidance and control system is non-stationary and nonlinear, the control input gains must be calculated for each linearized point of the missile flight.

Nelson defined the quadratic performance index of the linear quadratic regulator (LQR) controller for the design of the roll attitude control autopilot [4]. The objective of the LQR controller is to control the roll angle by minimizing a quadratic performance index (or cost function) which ensures that the roll angle, the roll rate and the aileron deflection are within specified limits. The optimum roll attitude autopilot control law is determined by solving the steady state matrix Riccati equation and this control law is a function of the roll angle and the roll rate.

Talole applied the quadratic performance index composed of the state parts and control parts [6]. The weighting matrix of the state parts includes the inverse values of the maximum allowed roll angle and the maximum allowed roll rate. The weighting matrix of the control part includes the inverse values of the maximum allowed roll control. The simulation results showed that the proposed design was robust and offered satisfactory performances in the presence of large external disturbances.

Nesline showed that modern roll autopilot designs with adequate stability characteristics can easily go unstable by increasing the complexity of the object model and he proposed a modification of the weighting factors within the performance index based on the crossover frequency and the stability margin of the open-loop system [7]. If the crossover frequency is too high, the system may go unstable when it is built and tested. It was shown that the crossover frequency, the gain and the stability margin can be modified by adjusting the weighting coefficients in the performance index. This approach gave the control system engineer the flexibility required to design a practical system using modern control methods.

Detailed analysis of the roll autopilot with the roll rate feedback in the inner loop and the roll angle feedback in the outer loop are given in [8]. Influence of the roll rate and roll angle gains to the stability of the roll autopilot closed loop is analyzed by root locus techniques. It was shown that increasing roll rate gain the limiting value of the roll angle gain is also increased.

The purpose of this paper is to present how the roll attitude autopilot for subsonic missiles controlled by aerodynamic interceptors is designed applying both the classical and optimal control theory Since there are only maximum positive and maximum negative deflections of aerodynamic interceptors, the pulse width modulation of the interceptors deflection is applied for the realization of the demanded roll commands. The wind tunnel model of the missile controlled by aerodynamic interceptors is used for the analysis of the roll attitude autopilot efficiency.

\section{Roll Control in a Missile with Aerodynamic Interceptors}

A missile roll control is done by the roll moment created with either differentially deflected hinged fins or ailerons which usually make part of the trailing edge of the wings. A choice of the aerodynamic configuration for the roll control depends on the missile size and the wing size.

An alternative for the roll control with ailerons is the roll 
control with aerodynamic interceptors (Fig.1). Aerodynamic interceptors are surfaces fitted normally to the wing. They are used in pairs in order to generate the roll moment. The basic characteristic of missiles controlled with aerodynamic interceptors is having fixed either a positive deflection or a negative deflection of these interceptors. Since there are only two possible fixed deflections of interceptors, either a positive one or a negative one, a constant positive roll moment or a constant negative roll moment can be generated.

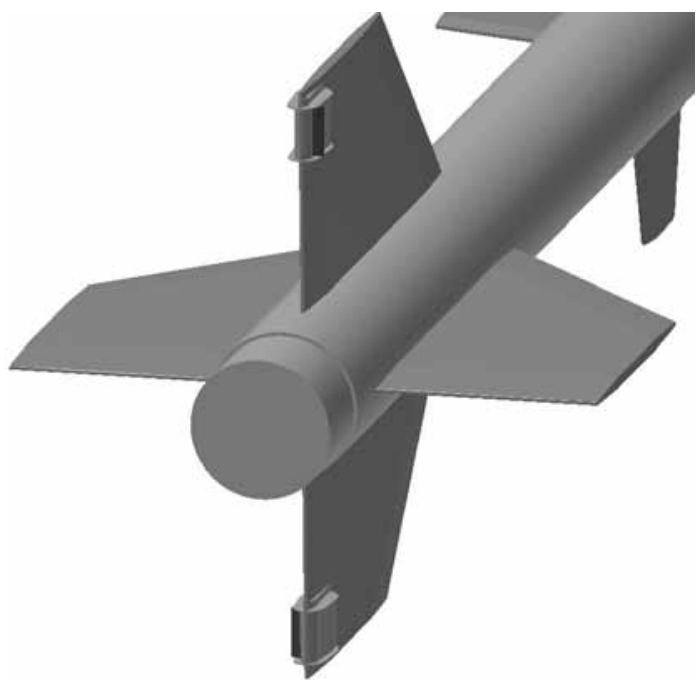

Figure 1. Aerodynamic configuration of the missile with interceptors

It is defined, by convection, that the positive deflection of interceptors (the positive roll command $\xi$ ) generates the negative roll moment $-L$ (Fig.2).

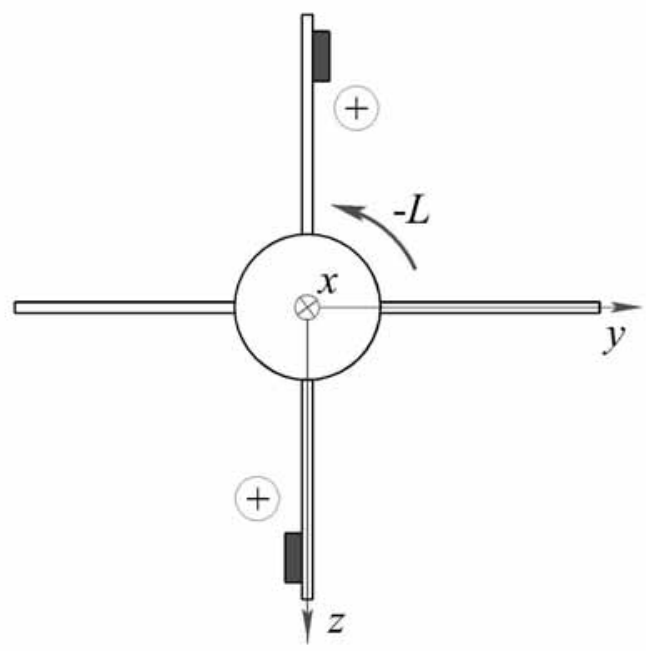

Figure 2. Aerodynamic configuration with interceptors

Aerodynamic interceptor deflection is realized by two opposite solenoid coils with a soft magnetic circuit forming two electromagnets and an iron armature, fastened to a carrier of the aerodynamic interceptor which can pivot around the hinge axis (Fig.3). The magnetic fields of the electromagnets are changed quickly by controlling the direction of the electric current in the electromagnet coils. The electric current directed to the coil of one electromagnet creates the electromagnetic field which attracts the armature, thus deflecting the aerodynamic interceptor in one direction. The opposite deflection of the aerodynamic interceptor is realized by directing the electric current to the coil of the opposite electromagnet. Such bistable mode of operation is provided with two complementary current signals obtained by a microcontroller and a power amplifier.

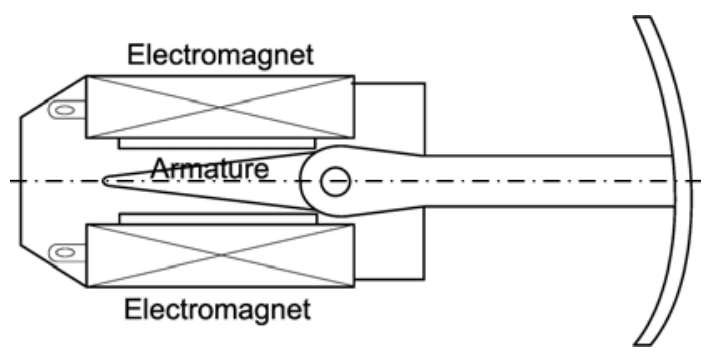

Figure 3. Actuation of the aerodynamic interceptor

Demanded arbitrary commands for the roll control can be realized by pulse width modulation (PWM) of the positive and negative deflection of aerodynamic interceptors during the predefined PWM time interval $T_{P W M}$. This PWM modulation is generated by splitting the PWM time interval $T_{P W M}$ to the time interval of the positive deflection of the interceptor $T_{1}$ and the time interval of the negative deflection of the interceptors $T_{2}$ (Fig.4).

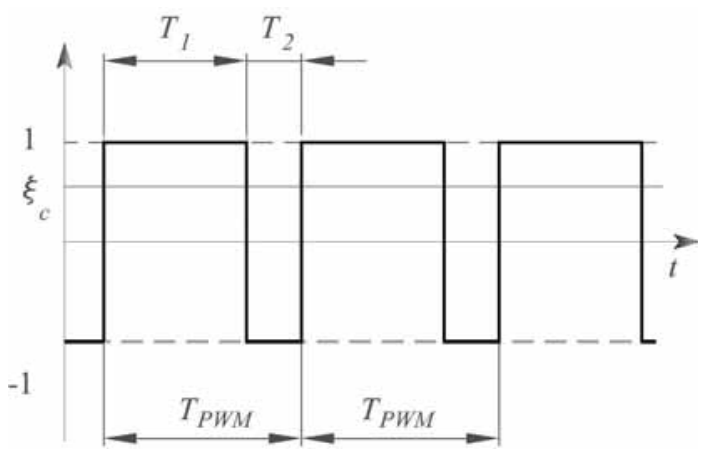

Figure 4. Pulse width modulation

The time interval of the positive deflection of the interceptor $T_{1}$ can be determined as a function of the demanded roll command $\xi_{c d}$.

$$
T_{1}=\frac{T_{P W M}}{2}\left(1+\xi_{c d}\right)
$$

\section{Roll Autopilot Design}

A widely used roll attitude autopilot for missile roll angle control is a two-loop roll autopilot with the roll rate feedback in the inner loop and the roll angle feedback in the outer loop [4]. The block diagram of the roll attitude autopilot for missiles controlled by aerodynamic interceptors is given in Fig.5. In a modern autopilot all functions of the roll autopilot encircled by a dashed line are solved numerically in controller with the $\mathrm{A} / \mathrm{D}$ and $\mathrm{D} / \mathrm{A}$ converter.

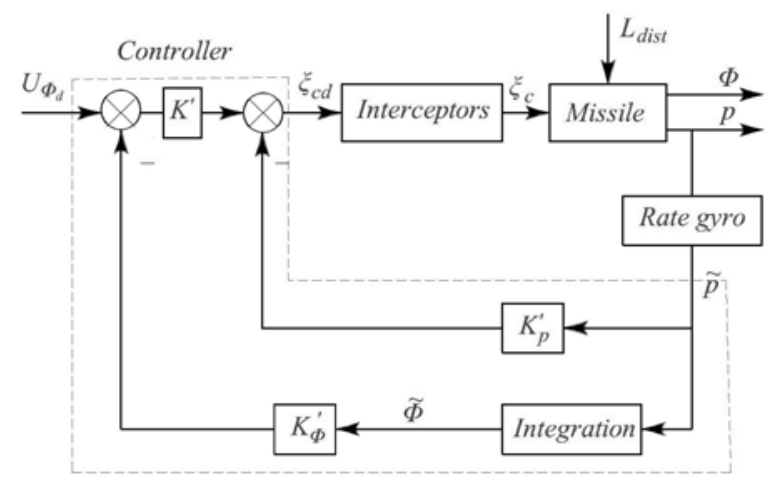

Figure 5. Roll attitude control system 
The missile transfer function is a function of the roll moment derivative due to the interceptor deflection $L_{\xi}$, the roll damping derivative $L_{p}$ and the longitudinal moment of inertia of the missile $I_{x}$.

$$
W_{\xi}^{p}(s)=\frac{K_{\phi}}{T_{\phi} s+1}=\frac{-L_{\xi} / L_{p}}{-\left(I_{x} / L_{p}\right) s+1}
$$

The roll damping derivative $L_{p}$ was calculated by the semiempirical build up method for the calculation of the aerodynamic coefficients derivatives and the wind tunnel experiments with a wind tunnel model of the missile with interceptors [9-12]. The roll moment derivative due to the interceptor deflection $L_{\xi}$ was determined from the wind tunnel measurement of the static aerodynamic coefficients. Since these derivatives are constant for subsonic Mach numbers up to $M=0.5$, the gain and the time constant of the roll transfer function of the missile are constant for these Mach numbers.

$$
W_{\xi}^{p}(s)=\frac{K_{\phi}}{T_{\phi} s+1}=\frac{-14.2}{0.32 s+1}
$$

The transfer function of the interceptor actuation system can be represented as the first order element with the gain $K_{a}=1$ and the time constant $T_{a}=0.01 \mathrm{~s}$.

$$
W_{a}(s)=\frac{-K_{a}}{T_{a} s+1}=\frac{-1}{0.01 s+1}
$$

The disturbing moment can be transformed to the equivalent interceptor roll control

$$
\xi_{\text {dist }}=\frac{L_{\text {dist }}}{L_{\xi}}
$$

where $L_{\text {dist }}$ - the disturbing moment due to asymmetric pressure on the lifting surfaces, $L_{\xi}$ - the aerodynamic derivative due to interceptors deflection and $\xi_{\text {dist }}$ - the equivalent disturbing interceptor roll control.

The block diagram of the attitude control system (Fig.5) can be transformed into a new one with the unity feedback in the outer loop where:

$$
K=K^{\prime} K_{\phi} K_{a}\left[\frac{\mathrm{rad}}{\operatorname{volt}} \frac{\mathrm{volt}}{\mathrm{rad}}=-\right], K_{p}=K_{a} K_{p}^{\prime}\left[\frac{\mathrm{rad}}{\mathrm{volt}} \frac{\mathrm{volt}}{\mathrm{rad} / \mathrm{s}}=s\right]
$$

(Fig.6).

The sampling interval can be represented as the transfer function of the pure delay element. There are two sampling intervals: one sampling interval is due to the controller $\left(T_{c}=1\right.$ $\mathrm{ms}$ ) and the second one is due to the pulse width modulation of the interceptors $\left(T_{P W M}=50 \div 100 \mathrm{~ms}\right)$. Since the sampling interval of the controller is much smaller than the interceptors PWM time interval it can be neglected for a definition of the pure delay transfer function time constant.

The pure delay time constant can be taken as a half of the interceptors PWM time interval $T_{p d}=T_{P W M} / 2$ [1].

$$
W_{p d}(s)=e^{-T_{p d} s}
$$

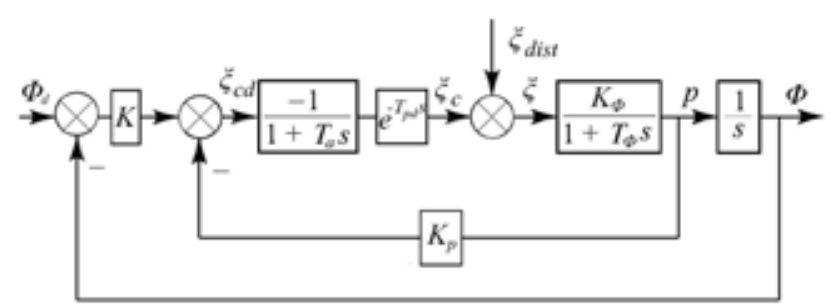

Figure 6. Roll attitude control system with the unity feedback in the outer loop

\section{Design of the simplified roll attitude control system}

Since the dynamics of the interceptors is much faster than the dynamics of the missile, it can be treated as a non-inertial element $W_{a}(s)=-1$. The pure delay element can also be neglected at lower frequencies near the expected cross-over frequency. The simplified block diagram of the roll autopilot is given in Fig.7.

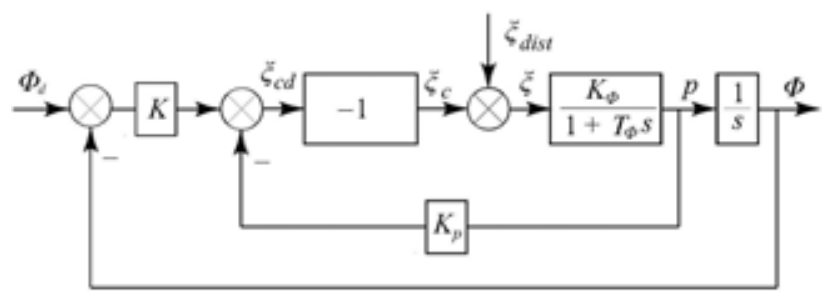

Figure 7. Simplified roll attitude control system with the unity feedback in the outer loop

The overall transfer function of the roll angle $\phi$ relative to the demanded roll angle $\phi_{d}$ is given by the following formula

$$
\frac{\phi}{\phi_{d}}(s)=\frac{1}{\frac{T_{\phi}}{-K K_{\phi}} s^{2}+\frac{1-K_{p} K_{\phi}}{\left(-K K_{\phi}\right)} s+1}=\frac{1}{\frac{1}{\omega_{n \phi}^{2}} s^{2}+\frac{2 \varsigma_{n \phi}}{\omega_{n \phi}} s+1}
$$

where the steady state value equals unity $\left(\frac{\phi}{\phi_{d}}\right)_{s \rightarrow 0}=1$

Based on equation (7), the gains $\mathrm{K}$ and $K_{p}$ can be determined for the given values of the natural frequency $\omega_{n_{\phi}}$ and the damping factor $\varsigma_{n_{\phi}}$ of the second order element transfer function.

$$
K=-\frac{\omega_{n_{\phi}}^{2} T_{\phi}}{K_{\phi}}, \quad K_{p}=\frac{1-2 \varsigma_{n_{\phi}} T_{\phi} \omega_{n_{\phi}}}{K_{\phi}}
$$

The transfer function of the roll angle $\phi$ relative to the equivalent disturbing roll control $\xi_{\text {dist }}$ can be obtained easily from the block diagram in Fig.7.

$$
\frac{\phi}{\xi_{\text {dis }}}(s)=-\frac{1}{K} \frac{1}{\frac{T_{\phi}}{-K K_{\phi}} s^{2}+\frac{1-K_{\phi} G_{R}}{-K K_{\phi}} s+1}
$$

Due to the steady state value of the transfer function (9) $\left(\phi / \xi_{\text {dis }}\right)_{s \rightarrow 0}=-1 / K$, a high value of the gain $K$ is required to reduce the effect of the disturbing moment.

Table 1 gives the calculated values of the gains $K, K_{p},(8)$, the settling time $t_{s}$ of the closed loop and the steady state value of the roll angle relative to the equivalent disturbing roll control (9) for the desired values of the natural frequency $\omega_{n_{\phi}}$ and the damping factor $\varsigma_{n_{\phi}}$.

Table 1. Roll autopilot parameters

\begin{tabular}{|c|c|c|c|c|c||}
\hline$\omega_{n_{\phi}}[\mathrm{rad} / s]$ & $S_{n_{\phi}}$ & $t_{s}[s]$ & $K$ & $K_{p}$ & $\left(\phi / \xi_{\text {dis }}\right)_{s \rightarrow 0}$ \\
\hline \hline 6.0 & 0.7 & 0.952 & 0.81 & 0.12 & 1.23 \\
8.0 & 0.7 & 0.714 & 1.44 & 0.18 & 0.69 \\
10.0 & 0.7 & 0.571 & 2.25 & 0.25 & 0.44 \\
\hline
\end{tabular}

Based on the wind tunnel measurements and the maximum allowed tolerance of the wing misalignment, the maximum equivalent disturbing roll control is estimated to be 
$\xi_{\text {distmax }}=0.2$. If it is assumed that the maximum allowed error in the roll angle $\phi<10^{\circ}$ and having in mind the steady state values of the transfer function (9), the gains in the range $K=1.44 \div 2.25$ and $K_{p}=0.18 \div 0.25$ can be taken as the initial values for the analysis of the roll autopilot.

LQR controller of the simplified roll attitude control system

Based on the transfer function of the missile roll channel, the equation of motion for the missile roll motion can be written in the following form

$$
\begin{aligned}
\frac{d}{d t} p & =-\frac{1}{T_{\phi}} p+\frac{K_{\phi}}{T_{\phi}} \xi \\
\frac{d}{d t} \phi & =p
\end{aligned}
$$

If the dynamics of the aerodynamic interceptor system is neglected, the missile roll response to the command can be written in the state space form, having in the mind the minus sign of the actuation system

$$
\dot{\mathbf{x}}_{r}=\mathbf{A}_{r} \mathbf{x}_{r}+\mathbf{B}_{r} \mathbf{u}
$$

where

$$
\begin{gathered}
\mathbf{x}_{r}=\left[\begin{array}{c}
\phi \\
p
\end{array}\right], \quad \mathbf{u}=[\xi], \quad \mathbf{A}_{r}=\left[\begin{array}{cc}
0 & 1 \\
0 & -\frac{1}{T_{\phi}}
\end{array}\right], \\
\mathbf{B}_{r}=\left[\begin{array}{c}
0 \\
\frac{-K_{\phi}}{T_{\phi}}
\end{array}\right]
\end{gathered}
$$

A special case of the application of the optimal control to the missile guidance and control system is regulating control where the desired state values are zero. The optimal regulating control for the roll attitude autopilot can be obtained by minimizing the quadratic performance index $[4,6,7]$.

$$
J=\int_{0}^{\infty}\left[\left(\frac{\phi}{\phi_{\max }}\right)^{2}+\left(\frac{p}{p_{\max }}\right)^{2}+\left(\frac{\xi}{\xi_{\max }}\right)^{2}\right] d t
$$

Having in mind the state space form of the missile roll channel (11), the quadratic performance index (13) can be written in the matrix form.

$$
J=\int_{0}^{\infty}\left(\mathbf{x}_{r}^{T} \mathbf{Q} \mathbf{x}_{r}+\mathbf{u}^{T} \mathbf{R} \mathbf{u}\right) d t
$$

The weighting functions $\mathbf{Q}$ and $\mathbf{R}$ are chosen in the following form

$$
\mathbf{Q}=\left[\begin{array}{ll}
\frac{1}{\phi_{\max }^{2}} & \\
& \frac{1}{p_{\max }^{2}}
\end{array}\right], \quad \mathbf{R}=\left[\frac{1}{\xi_{\max }^{2}}\right]
$$

The optimal control obtained by the minimization of the quadratic performance index (14) is called the linear quadratic regulator $(\mathrm{LQR})$. The input control $\mathbf{u}$ is a linear function of the state vector.

$$
\mathbf{u}=-\mathbf{K} \mathbf{x}_{r}=-\mathbf{B}_{r} \mathbf{S} \mathbf{x}_{r}
$$

where $\mathbf{S}$ is the solution of the Riccatti matrix equation

$$
\mathbf{S A}{ }_{r}+\mathbf{A}_{r}^{T} \mathbf{S}+\mathbf{S} \mathbf{A}_{r} \mathbf{R}^{-1} \mathbf{B}_{r}^{T} \mathbf{S}+\mathbf{Q}=0 .
$$

Since the roll autopilot is controlled by aerodynamic interceptors, the maximum roll command equals unity $\xi_{\max }=1.0$ and $\mathbf{R}=[1]$.

Substituting the matrices $\mathbf{A}_{r}, \mathbf{B}_{r}, \mathbf{Q}$ and $\mathbf{R}$ into the Riccati equation leads to the unknown elements of the $\mathbf{S}$ matrix becoming a solution of the set of nonlinear algebraic equations.

$$
\begin{aligned}
& -\left(\frac{-K_{\phi}}{T_{\phi}}\right)^{2} s_{12}^{2}+\frac{1}{\phi_{\max }^{2}}=0 \\
& s_{11}-\frac{1}{T_{\phi}} s_{12}-\left(\frac{-K_{\phi}}{T_{\phi}}\right)^{2} s_{12} s_{22}=0 \\
& 2 s_{12}-\frac{2}{T_{\phi}} s_{22}-\left(\frac{-K_{\phi}}{T_{\phi}}\right)^{2} s_{22}^{2}+\frac{1}{p_{\max }^{2}}=0
\end{aligned}
$$

The parameters of the gain $\mathbf{K}=\left[\begin{array}{ll}K & K_{p}\end{array}\right]$ depend on the maximum allowed roll angle $\phi_{\max }$ and the maximum allowed roll rate $p_{\max }$ (Table 2 ).

Table 2. Optimal roll autopilot gains

\begin{tabular}{||c|c|c|c||}
\hline \hline$\phi_{\max }$ & $p_{\max }$ & $K$ & $K_{p}$ \\
\hline \hline 0.40 & 6.0 & 2.5 & 0.48 \\
0.25 & 6.0 & 4.0 & 0.63 \\
0.15 & 6.0 & 6.7 & 0.84 \\
\hline
\end{tabular}

The gains for the optimal roll control are comparable to the gains obtained by classical linear control techniques.

\section{Influence of the time delay to the roll attitude control system stability}

The stability of the roll autopilot closed loop, with the included transfer function of the actuator of the aerodynamic interceptor and the pure delay element, can be verified by the Bode diagram of the open loop broken at the roll autopilot command (Fig.6).

Crossover frequencies and phase margins are given in Table 3 for three values of the gains $K=2.0,4.0,6.0$ and three values of the gain $K_{p}=0.4,0.6,0.8$. Phase margins are given for two values of time delay $T_{p d}=0.05,0.025 \mathrm{~s}$.

Table 3. Gain and phase margin

\begin{tabular}{||c|c|c|c|c||}
\hline \multirow{2}{*}{$K_{p}$} & & & $T_{p d}=0.05 s$ & $T_{p d}=0.025 s$ \\
\hline \hline \multirow{3}{*}{0.4} & 2.0 & 6.62 & 48.7 & $\phi_{m}\left[{ }^{\circ}\right]$ \\
\cline { 2 - 5 } & 4.0 & 8.37 & 26.0 & 58.2 \\
\cline { 2 - 5 } & 6.0 & 9.86 & 12.1 & 38.0 \\
\hline \multirow{3}{*}{0.6} & 2.0 & 8.66 & 53.6 & 26.3 \\
\cline { 2 - 5 } & 4.0 & 9.82 & 34.8 & 66.0 \\
\cline { 2 - 5 } & 6.0 & 11.0 & 21.3 & 48.9 \\
\hline \multirow{3}{*}{0.8} & 2.0 & 11.2 & 50.3 & 37.1 \\
\cline { 2 - 5 } & 4.0 & 11.8 & 37.1 & 66.3 \\
\cline { 2 - 5 } & 6.0 & 12.7 & 25.8 & 44.0 \\
\hline
\end{tabular}

There is an increase of the crossover frequency and phase margin with increase of the gains $K_{p}$ and $K$. The phase margin is increased with the increase of the gain $K_{p}$, and the phase margin is decreased with the decrease of the gain $K$. Better characteristics of the roll attitude control system can be obtained with the decrease of the PWM time interval and thus 
with the decrease of the time delay constant $T_{p d}$.

The magnitude and the phase curves of the Bode diagram (Fig.8) are given for the gain $K_{p}=0.4$ and three gains $K=2.0,4.0,6.0$.

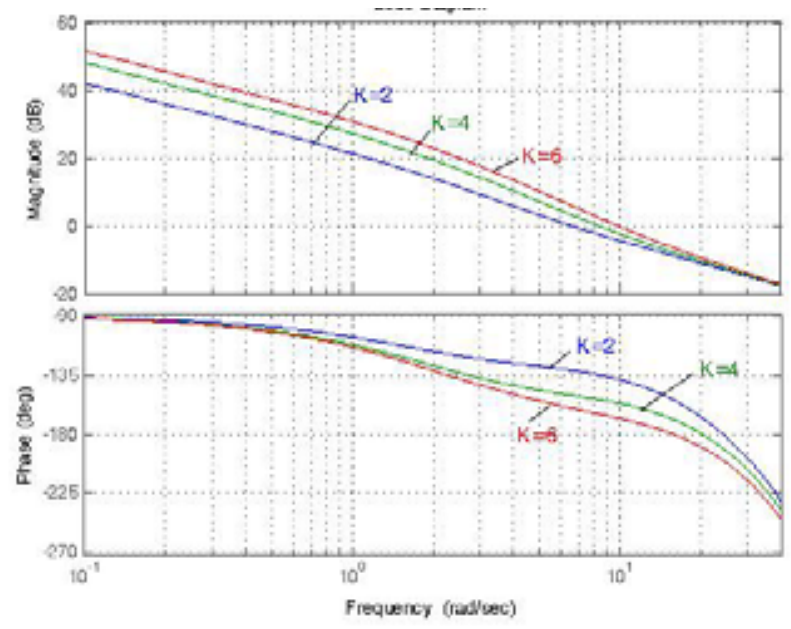

Figure 8. Bode diagram of the open loop

\section{Transfer Function of the Missile Wind Tunnel Model}

A missile model with a roll autopilot was tested in the T-35 continuous type wind tunnel of Vojnotehnički Institut (VTI Militry Technical Institute). The test section length is $5.5 \mathrm{~m}$ and the area of the octagonal cross-section is $11.93 \mathrm{~m}^{2}$. Different Mach number values are obtained by changing fan rotation rates and the angles of fan blades. The total pressure in the test section is slightly over 1 bar, and the test duration is not limited.

The Micro-Electro-Mechanical Systems (MEMS) rate gyro used for the roll rate measurement was InvenSense MPU6050 with the following features: Digital output; Full scale range of $\pm 250 \%$; Integrated 16-bit Analog-to-Digital convertor; Output data rate of $8 \mathrm{kHz}$, Total Root-MeanSquared Noise is $0.05 \%$ s.

The micro-controller for all autopilot functions calculation, including the integration of the roll rate in order to obtain the roll angle, was Espressif Systems 32-bit microcontroller ESP8266 with Central-Processing-Unit clock on $160 \mathrm{MHz}$. The roll rate sampling and integration time interval was $0.2 \mathrm{~ms}$.

A photograph of the missile model in the wind tunnel is given in Fig.9.

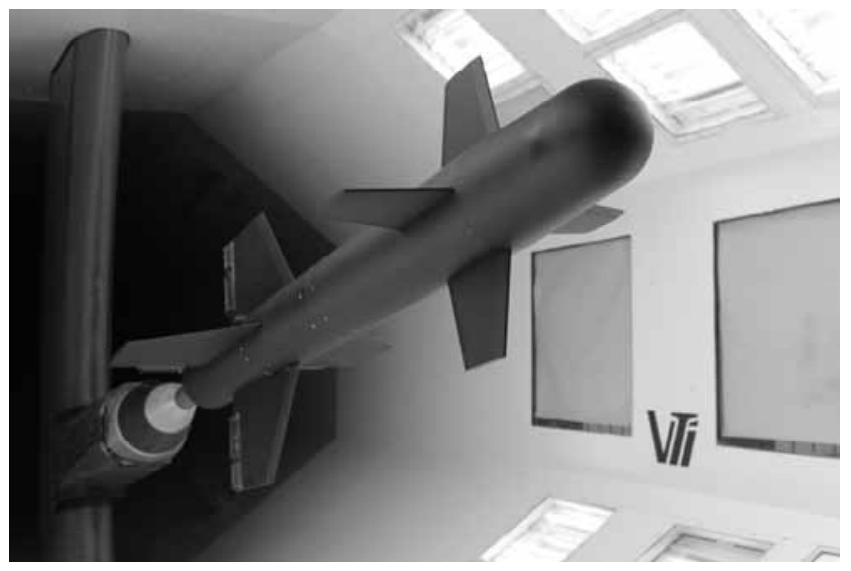

Figure 9. Wind tunnel model with the roll autopilot
The balance, the free rotating adaptor and the model are mounted on a tail sting support. During the run, the free rotating adaptor enables rotation of the model around the longitudinal axis of the model support system (Fig.10).

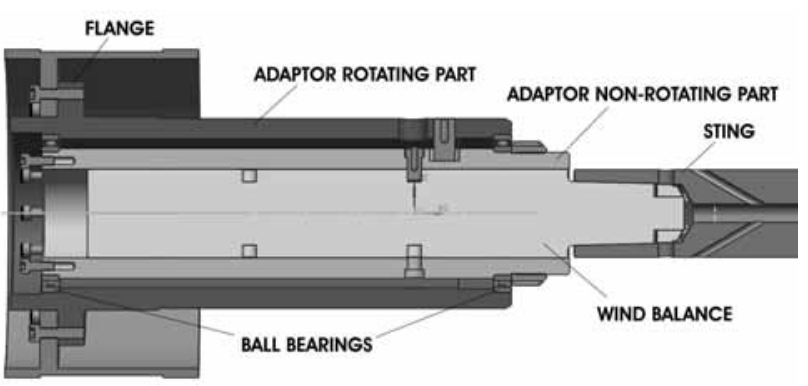

Figure 10. Wind tunnel free rotating adaptor

The roll rate of the missile $p$ depends on a demanded command and the PWM time interval $T_{P W M}$. The zero demanded command is realized by splitting the PWM interval $T_{P W M}$ into two equal time intervals $T_{P W M} / 2$, where the time interval of the positive interceptors deflection $T_{1}=T_{P W M} / 2$ is equal to the negative interceptors deflection time interval $T_{2}=T_{P W M} / 2$. The measured missile roll rates for the zero demanded command are illustrated in Fig.11 for the PWM times $T_{P W M}=0.2 s$ and $T_{P W M}=0.1 s$, while the measured roll rates for the PWM time intervals $T_{P W M}=0.08 \mathrm{~s}$ and $T_{P W M}=0.06 \mathrm{~s}$ are given in Fig.12. It is evident that there are oscillations of the missile even for the zero demanded command. The mean roll rate is equal zero and the roll rate oscillation amplitude decreases with the decrease of the PWM time interval.

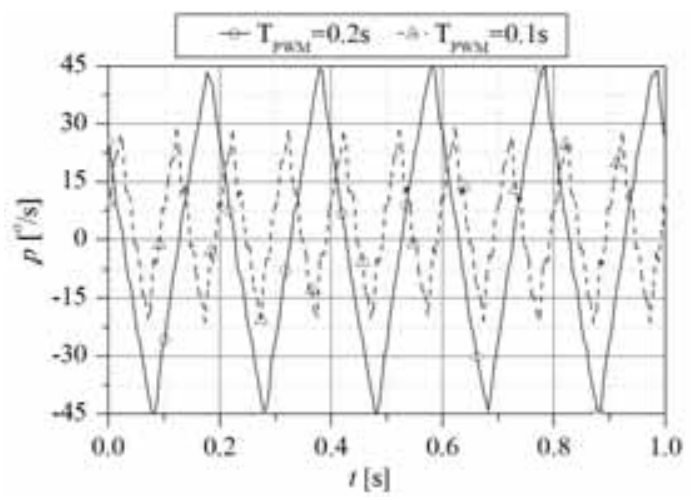

Figure 11. Measured wind tunnel model roll rate for the zero command and $T_{P W M}=0.2 s, 0.1 s$

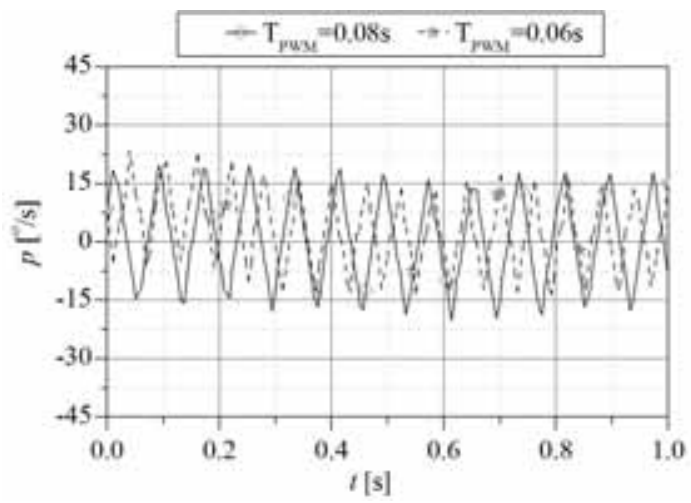

Figure 12. Measured wind tunnel model roll rate for the zero command and $T_{P W M}=0.08 s, 0.06 s$ 
The transfer function of the wind tunnel model with the ball bearing friction can be determined from the transient response of the wind tunnel model due to the change of the demanded roll command from $\xi_{c d}=0.5$ to $\xi_{c d}=0.75$ (Fig.13).

$$
W_{\xi(W T)}^{p}(s)=\frac{K_{\phi(W T)}}{T_{\phi(W T)} S+1}
$$

Since the steady state value of the wind tunnel model roll rate for the command $\xi_{c d}=0.5$ is $p=-180 \% s=-\pi \mathrm{rad} / \mathrm{s}$ and for the command $\xi_{c d}=0.75$ it is $p=-270 \% \mathrm{~s}=-\frac{3 \pi}{2} \mathrm{rad} / \mathrm{s}$, the gain of the transfer function of the wind tunnel model is $K_{\phi(W T)}=-6.28 \mathrm{rad} / \mathrm{s}$. The time constant $T_{\phi(W T)}$ of the transfer function (8) is determined by adjusting the calculated response of the transfer function to the measured roll rate of the wind tunnel model due to sudden change he demanded command from $\xi_{c d}=0.5$ to $\xi_{c d}=0.75$

(Fig.13). There are two curves of the calculated response of the transfer function to the demanded command. One curve is a response of the transfer function to the demanded command and the other one is a response of the demanded command to PWM interceptor deflection. A complete match of the calculated response of the transfer function and the measured response of the wind tunnel model is obtained for $T_{\phi(W T)}=0.45$.

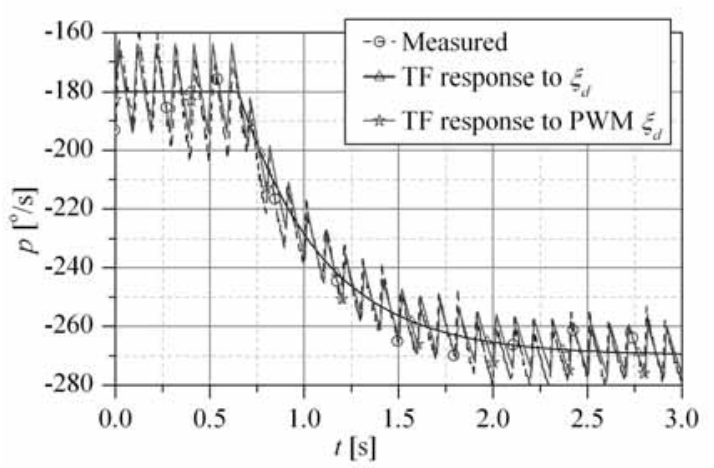

Figure 13. Transient response from the command $\xi=0.5$ to the command $\xi=0.75$

The transfer function of the closed loop of the roll attitude autopilot (the response of the roll angle $\phi$ relative to the demanded roll angle $\phi_{d}$ ) for the missile wind tunnel model can be obtained by substituting the parameters of the wind tunnel model transfer function $K_{\phi(W T)}=-6.28 \mathrm{rad} / \mathrm{s}$ and $T_{\phi(W T)}=0.45$, and the roll autopilot gains $K=2.0$ and $K_{p}=0.3$ into the equation (7).

$$
\begin{aligned}
\frac{\phi}{\phi_{d}}(s) & =\frac{1}{\frac{T_{\phi_{(W T)}}}{-K K_{\phi_{(W T)}}} s^{2}+\frac{1-K_{p} K_{\phi(W T)}}{\left(-K K_{\phi_{(W T)}}\right)} s+1}= \\
& =\frac{1}{\frac{1}{5.283^{2}} s^{2}+\frac{2 \cdot 0.606}{5.283} s+1}
\end{aligned}
$$

The natural frequency and the damping factor of the closed loop transfer function are $\omega_{n_{\phi}}=5.283 \mathrm{rad} / \mathrm{s}$ and $\varsigma_{n_{\phi}}=0.606$.

\section{Numerical Simulations and Measurements of the Roll Autopilot Response}

The roll attitude autopilot, given in Fig.6, with the PWM command for the input of the missile transfer function, was built in the SIMULINK toolbox of the MATLAB software package. The results of the numerical simulation and the measured response of the wind tunnel model are given inFigures 14-16 for the step input of the demanded roll angle $\phi_{d}=45^{\circ}$, the gains of the roll autopilot $K=2.0$ and $K_{p}=0.3$, and the PWM time interval $T_{P W M}=0.1 \mathrm{~s}$. The diagram representing the calculated roll angle of the missile wind tunnel model is in agreement with the measured roll angle diagram (Fig.14). When the missile roll rate (Fig.15) is concerned, the amplitude of the calculated roll rate in the steady state condition is $5 \% \mathrm{~s}$ less than the amplitude of the measured roll rate. The diagrams of the demanded commands $\xi_{c d}$ and the realized PWM commands $\xi_{P W M}$ are given in Fig.16. The demanded commands are constant during the PWM time interval and the realized PWM commands are the input for the wind tunnel model transfer function.

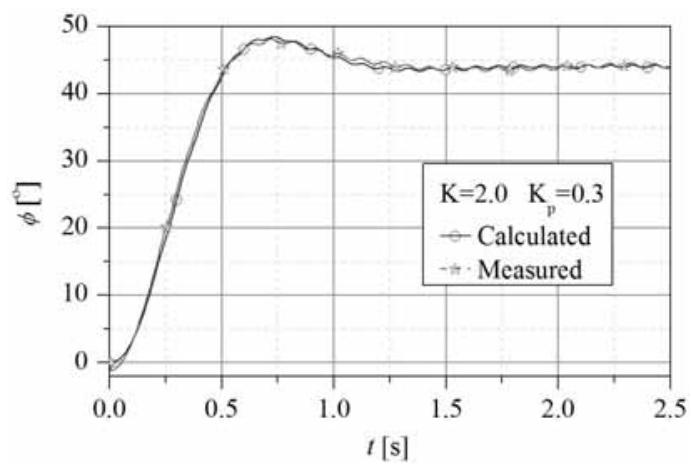

Figure 14. Roll angle response

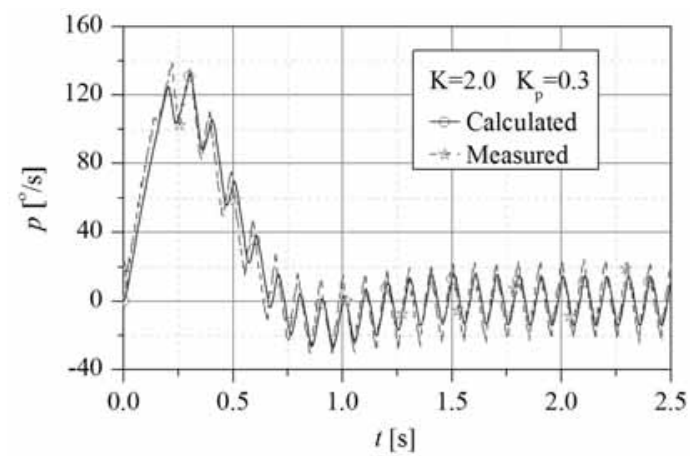

Figure 15. Roll rate response

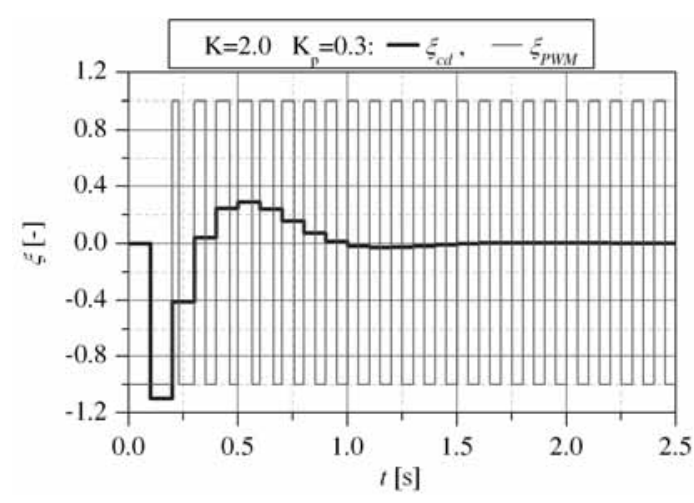

Figure 16. Demanded and realized PWM commands 
The influence of the gains $K$ and $K_{p}$, and the PWM time interval $T_{P W M}$ on the wind tunnel model response is analyzed by changing the demanded roll angle from $\phi_{d}=0^{\circ}$ to $\phi_{d}=45^{\circ}$. The response of the wind tunnel model is measured for four values of the gains $\mathrm{K}=0.5,1.0,1.5,2.0$ and $\mathrm{K}_{\mathrm{p}}=0.1$, $0.1,0.2,0.3$, respectively.

The diagrams of the measured roll angles are given in Fig. 17 and those of the roll rates in Fig. 18 for $T_{P W M}=0.1 \mathrm{~s}$. There are oscillations of the wind tunnel model during the response. The amplitude of the roll angle oscillations in the steady state condition is $0.3^{\circ}$.

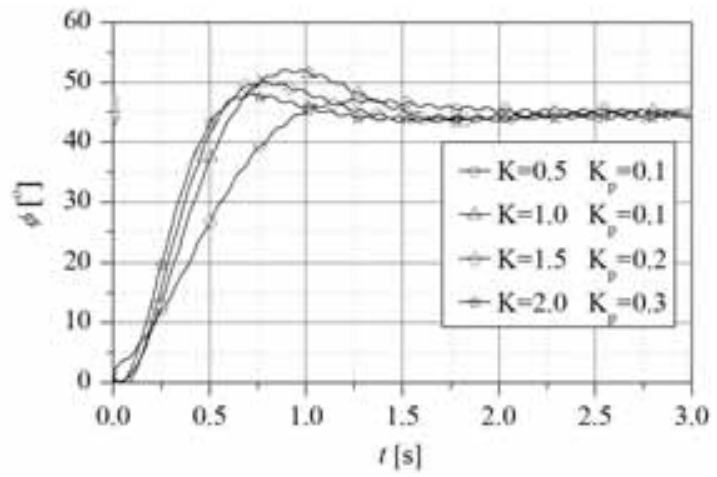

Figure 17. Influence of the autopilot gains on the roll angle response for $\phi_{d}=45^{\circ}$ and $T_{P W M}=0.1 \mathrm{~s}$

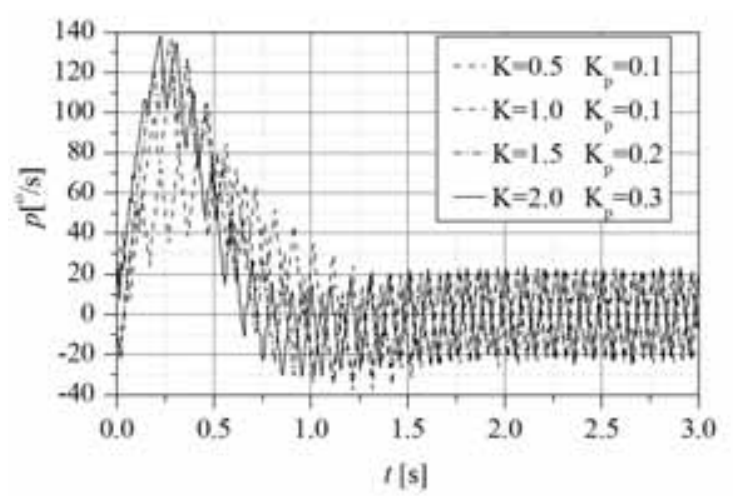

Figure 18. Influence of the autopilot gains on the wind tunnel model roll rate for $\phi_{d}=45^{\circ}$ and $T_{P W M}=0.1 s$

If the PWM time interval is decreased to $T_{P W M}=0.05 \mathrm{~s}$, the roll angle oscillation amplitude in the steady state condition decreases to $0.08^{\circ}$ (Fig.19). Also, decreasing the PWM time interval from $T_{P W M}=0.1 \mathrm{~s}$ to $T_{P W M}=0.05 \mathrm{~s}$ results in the decrease of the roll rate oscillation amplitude in the steady state condition from $10^{\circ}$ s to (Fig.20).

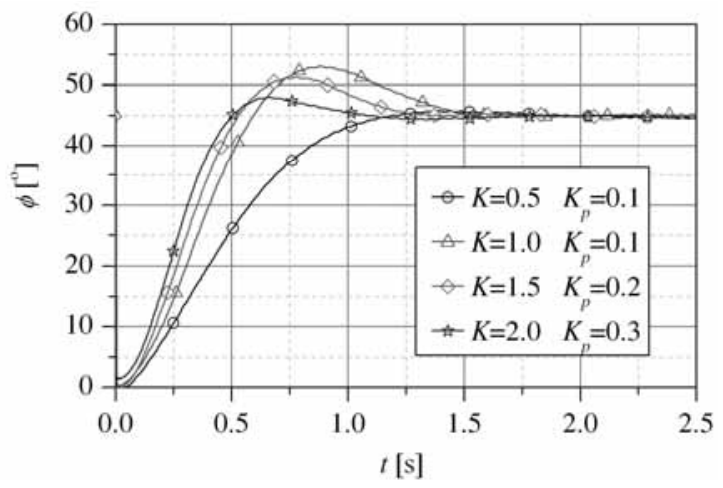

Figure 19. Influence of the autopilot gains on the roll angle response for $\phi_{d}=45^{\circ}$ and $T_{c}=0.05 \mathrm{~s}$

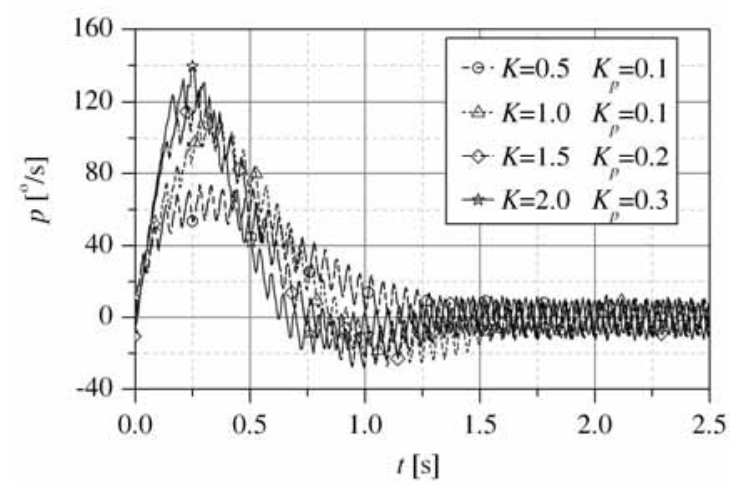

Figure 20. Influence of the autopilot gains on the wind tunnel model roll rate for $\phi_{d}=45^{\circ}$ and $T_{c}=0.05 \mathrm{~s}$

The transient response of the wind tunnel model can lead to the conclusion that the transient response does not depend on the PWM time interval. The settling time of the wind tunnel model transient response decreases with the increase of the gain $K$, and this time is reduced to $0.9 s$ when the autopilot gains are increased to the values of $K=2.0$ and $K_{p}=0.3$.

\section{Conclusion}

The basic characteristic of the missiles controlled by aerodynamic interceptors is the existence of two deflections of interceptors, equal in magnitude, where the first one is positive and the second one is negative. Demanded commands for the roll control are realized by pulse width modulation of the positive and negative deflections of aerodynamic interceptors during a predefined modulation time interval.

The roll attitude autopilot of the missile controlled by aerodynamic interceptors, with roll rate and roll angle feedback, is designed with the help of both classical and optimal control theory. The roll autopilot gains obtained with the optimal control theory can be equal to the gains obtained by the classical control theory by adjusting the weighting coefficients in the performance index of the optimal control theory.

The efficiency of the roll autopilot of the missile controlled by aerodynamic interceptors is verified on the missile wind tunnel model mounted on a free rotating adaptor which enables movement around the longitudinal axis of the model support system. Based on the wind tunnel model response to the pulse width modulated demanded command, the transfer function of the wind tunnel model is determined. It has been shown that the roll autopilot designed for missiles controlled by aerodynamic interceptors can be applied to the wind tunnel model.

Based on the numerical simulation and the measured roll rate response of the wind tunnel model to the pulse width modulated zero demanded command, it has been shown that both the missile and the wind tunnel model oscillate around the zero roll rate due to pulse width modulation. These oscillations decrease with the decrease of the modulation time interval.

The wind tunnel measurements have shown that a faster response of the roll attitude autopilot is obtained with the increase of the roll angle feedback gain and that the overshoot decreases with the increase of the roll rate feedback gain. The amplitude of the roll angle oscillations in the steady state condition decreases with the decrease of the modulation time interval.

The research in this paper can be improved by development of the LQR controller for themissile roll attitude control system with the roll angle and roll rate feedback with added pure delay element transfer function and more accurate definition of the pure delay time constant of the PWM sampling interval. 


\section{References}

[1] MINOVIĆ,S.: Odabrana poglavlja iz vodjenja i upravljanja projektila, Univerzitet u Beogradu, Mašinski fakultet, Beograd, SRBIJA, 1971.

[2] GARNELL,P.: Guided Weapon Control System, Pergamon Press, Oxford, England, 1980.

[3] BLAKELOCK,J.H.: Automatic Control of Aircraft and Missiles, John Wiley \& Sons, Inc., New York, USA, 1991

[4] NELSON,R.C.: Flight Stability and Automatic Control, Second Edition, McGraw-Hill, Boston, USA, 1998.

[5] SIOURIS, G.M.: Missile Guidance and Control Systems, Springer, New York, USA, 2003.

[6] TALOLE,S.E., GODBOLE,A.A., KOLHE,J.P.: Robust Roll Autopilot Design for Tactical Missiles, Journal of Guidance Control and Dynamics, January-February 2011, Vol.34, No.1, pp.107-117.

[7] NESLINE,W.F., ZARCHAN,P.: Why Modern Controllers Can Go Unstable in Practice, Journal of Guidance and Control, July-August 1984, Vol.7, No.4, pp.495-500.
[8] ĆUK,D., ĆURČIN,M., MANDIĆ,S.: Autopilot Design - Theoretical Manual, Military Technical Institute, Belgrade, SERBIA, VTI-03-010801, 2004.

[9] NIELSEN,J.N.: Missile Aerodynamics, McGraw-Hill, New York, USA, 1960.

[10] ЛЕБЕДЕВ,А.А.: ЧЕРНОБРОВКИН,Л.С., Динамика полета беспилотних летателних аппаратов, Машиностроение, Москва, РУСИЈА, 1973.

[11] Hemsch,M.J., NIELSEN,J.N.: Tactical Missile Aerodynamics, American Institute of Aeronautics and Astronautics, New York, USA, 1986.

[12] ĆUK,D., ĆURČIN,M., MANDIĆ,S., NIKOLIĆ,D.: GMTC-3D Guided Missile Trajectory Calculation, Military Technical Institute, Belgrade, SERBIA, VTI-03-01-0688, 2002.

\title{
Efikasnost primene aerodinamičkih interceptora za kontrolu ugla valjanja rakete
}

\begin{abstract}
Izrazito valjanje raketa lansiranih sa aviona nastaje zbog aerodinamičke nesimetrije rakete, asimetričnog otklona upravljačkih krila, atmosferskih poremećaja i velikog poremećajnog momenta valjanja u blizini aviona pri silasku rakete sa lansera. Za eliminisanje neželjenih efekata valjanja rakete neophodno je da se ugradi autopilot valjanja koji kontroliše ugao valjanja bez obzira na dejstvo poremećaja. U radu je primenjena klasična teorija automatskog upravljanja $i$ teorija optimalnog upravljanja za projektovanje autopilota valjanja raketa sa ugaonom brzinom valjanja u unutrašnjoj i uglom valjanja u spoljašnjoj povratnoj petlji za rakete koje se upravljaju aerodinamičkim interceptorima. Primenom širinsko impulsne modulacije je pretovrena željena komanda za kontrolu autopilota valjanja u otklon aerodinamičkih interceptora. Efikasnost autopilota valjanja sa aerodinamičkim interceptorima je proverena u aerodinamičkom tunelu. Model rakete za ispitivanje u aerodinamičkom tunelu je postavljen na slobodnorotirajući adapter koji je omogućavao rotaciju modela oko uzdužne ose. Na osnovu odgovora modela rakete za zadate komande određena je preonosna funkcija modela koji je ispitivan u aerodinamičkom tunelu. Rezultati ispitivanja su pokazali uticaj pojačanja autopilota valjanja na odgovor aerotunelskog modela. Date su i analize uticaja širinsko modulisanih otklona aerodinamičkih inteceptora na neželjene oscilacije rakete.
\end{abstract}

Ključne reči: autopilot, avionska raketa, upravljanje raketom, valjanje rakete, ugao valjanja, aerodinamički interceptor, optimalno upravljanje, impulsna modulacija, aerodinamičko ispitivanje, rezultati ispitivanja.

\section{Эффективность применения аэродинамического межсектора для контроля диапазона катания ракеты}

\begin{abstract}
Чёткая прокатка ракет, запущенных с самолёта, связана с аэродинамическим разрушением ракеты, асимметричными дефектами рулевого крыла, атмосферными возмущениями и большим возмущением момента качения вблизи самолёта при убойной ракете ракеты-носителя. Чтобы устранить нежелательные эффекты качения в ракете, необходим установить скользящий автопилот, который контролирует угол качения независимо от эффекта беспорядка. В статье используется классическая теория автоматического управления и теория оптимального управления конструкцией ракетного автопилота со скоростью качения во внутренней и угловой катке во внешнем контуре обратной связи для ракет, управляемых аэродинамическими перехватчиками. Используя широтно-импульсную модуляцию, передается желаемая команда для управления сканированием автопилота при прогибе аэродинамических перехватчиков. Эффективность прокатки автопилота с аэродинамическими перехватчиками проверяется в аэродинамическом туннеле. Ракетная модель для испытания в аэродинамическом туннеле была установлена на переходнике свободного хода, что позволило вращать модель вокруг продольной оси. На основе реакции модели ракеты для данных элементов управления определяется переходная функция модели, исследованной в аэродинамическом туннеле. Результаты теста показали эффект усиления прокатки автопилота по отклику модели аэропункта. Также был дан анализ влияния широко модулированных аэродинамических пересечений на нежелательные ракетные колебания.
\end{abstract}

Ключевые слова: автопилот, авиационная ракета, управление ракетами, катание ракеты, угол катания, аэродинамический перехватчик, оптимальное управление, импульсная модуляция, аэродинамические испытания, результаты испытаний. 


\title{
Efficacité de l'application des intercepteurs aérodynamiques pour le contrôle de l'angle du roulement de missile
}

\begin{abstract}
Le roulement excessif des missiles lancés à partir de l'avion se produit à cause de l'asymétrie aérodynamique du missile, de l'écart asymétrique des ailes, des perturbations atmosphériques et du grand moment perturbé de roulement à proximité de l'avion pendant la descente du missile du lanceur. Pour éliminer les effets non désirés du roulement de missile il est nécessaire d'installer un autopilote de roulement qui contrôle l'angle de roulement malgré l'action de perturbation. Dans ce travail on a appliqué la théorie classique du contrôle automatique ainsi que la théorie de contrôle optimale pour la conception du pilote automatique du roulement de missile à la vitesse d'angle de roulement dans la boucle intérieure et l'angle de roulement dans la boucle extérieure réversible pour les missiles contrôlés par les intercepteurs aérodynamiques. La commande désirée pour le contrôle du pilote automatique de roulement a été transformée en déflexion des intercepteurs aérodynamiques par large modulation d'impulsion. L'efficacité de l'autopilote de roulement aux intercepteurs aérodynamiques a été vérifiée dans le tunnel aérodynamique. Le modèle de missile pour l'examen dans le tunnel aérodynamique a été monté sur un adaptateur qui tourne librement et qui a permis la rotation du modèle autour de l'axe longitudinal. A la base de la réponse du modèle de missile aux commandes données on a déterminé la fonction du transfert de modèle examiné dans le tunnel aérodynamique. Les résultats de l'examen ont démontré l'influence du renforcement de l'autopilote de roulement sur la réponse du modèle du tunnel aérodynamique. On a donné aussi les analyses de l'influence de la déflexion modulée largement des intercepteurs aérodynamiques sur les oscillations non désirées du missile.
\end{abstract}

Mots clés: autopilote, missile, contrôle de missile, roulement de missile, angle de roulement, intercepteur aérodynamique, contrôle optimale, modulations d'impulsions, examen aérodynamique, résultats d'examen. 